\title{
道路網における容量制約を考慮した確率最大化 配分法とその解法
}

\author{
PROBABILITY MAXIMIZATION MODEL FOR TRAFFIC \\ ASSIGNMENT WITH CAPACITY RESTRAIN'T AND \\ ITS ANALYTICAL METHODS
}

松 牛 筧 ${ }^{*}$
By Hiroshi Natsui

\section{1.まえがき}

自動車が道路網上をいかに走行するかを推定しよらと するいわゆる交通量配分の問題は, 古くから研究され, 現在までに多くの交通量配分モデルが提案されている。 ところで, 交通量配分の問題は, 運転者の経路選択挙動 にみられる複雑さに加えて, 一般に道路網を対象とした 場合, 扱う変数の数が非常に膨大となるなどの部算技術 上の問題もあって，計算の簡略化を重視するあまり，と もすれば配分理論としての論理性や数学的な厳密さに久 けるモデルが少なくない。しかしながら，最近の上らに 交通量配分の目的が単に道路網上に扔ける交通流の䛉述 にとどまらず，道路網の変化あるいは交通規制の契施に 伴ら交通流の変化の予測にまで適用されるょらになる 上，単に現奉の交通流との適合性のみを重視するだけで は不十分で, そこにはやはり現実にみられる配分現象に 対して論理的な説明がなされていなければならないと考 える。

ところで, 著者がすでに提案している確率最大化配分 法と名付けた新しい配分理論は, 運転者の経路選択にみ られる多様性を前提に, 最も確からしい配分パターンを 求めるもので, 綮密な論理性に裏付けされたモデルの一 つであるといらことができる。この配分モデルは道路網 上の配分現象を数学的に記述することを目的としたもの ごあるが，特にこの配分モデルに扔いて交通谷量制約を 掌人した場合は, 問題が非線形叶曲法り開題上なり,一 般に求解が困難上なる。

そこで本文では, 特に容量制約を考虑した場台ひ確济 最大化配分法を取り上げ，その具体的な解法についてい くつかの提案を行い，その実用化に対し検討を加えるこ とにした。

* 正会員 工修 名古屋工業大学講師 土杠工学科

\section{2. 確率最大化配分法の概要 ${ }^{11}$}

道路網上に打いて，ある目的地に问かう東がどの経路 を選択寸るかを，東1台1台について考えてみれば，き わめて多様性に富儿でいるといらことができる。これは 運転者の経路選択に影響を及ぼす要因がきわめて広螌囲 にわたっており，さらに，運転者が何本かの経路の中か ら走行経路を選択するとき，通常はそれらの経路を正確 に比較禑価するに十分な情報を，運転者自身持ち合わせ ていないためであると考えられる。ところが，このよう な人間行動の複雑さにもかかわらず, 個々の東の行動り 集合体として道路網上の交通流を朓めてみると, 一般に は恃間的ないし距離的に最短な経路を選ぶ確㳯が最も润 くなり，ついで次適経路がそれに綐く上いらような，あ る種の統汁们䙺則性を㤎めることができるであろう。

道路網上の交通流をこのような観点から眺めてみう 上，道路網上での運転者の経路選択を確摔的現象として とらえることに十分妥当性があると考えられる。確率最 大化配分法においては, 道路網上の交通量配分パターン が確率的な立場から論じられ，その結果与えられた道路 条件抢よび交通条件のもとで, 最も起こりやすい配分分 ターンといらものが導き出される。

すなわち，い文刘象上寸る道路絧上に

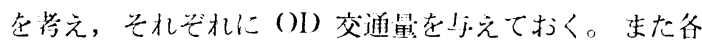
()リに刘しあらかじめたかだかs本までり配分対象経路 在指代して扩く。にだしここであらかじめ経路を指忘 したが，こ机はこり配分理論に扔いて本筫的な問題では ふい。後述するように，配分経路を指定せず，考えられ るすべての経路を対象として取り上げることも同様に问 能である。また，経路の評価值としてここでは所要時間 を取り上げることにする。

さて, いま $\boldsymbol{r}$ 種の $\mathrm{OD}$ 交通量がこの道路網上の経路に 配分さ机るわけであるが，このときこれらの交通奄によ 
る総走行時間がある任意の值をとるような配分パターン に注目してみる。いまこの配分状態を車 1 台 1 台区別し て見たとき，区別できる配分状態の数は，全体の交通量 が多いときは非常にたくさん存在する。このように車 1 台 1 台を区別して見た状態を微視的状態とよぶのである が，いま車 1 台 1 台を区別しないである任意の配分状態 を考えたときの，その配分状態に対応する微視的状態の 数を数え上げてみよう。このときこれらの微視的状態が す心゙て等確摔で生起すると仮定すれば，微視的状態の数 が最も多くなる配分状態が最も起こりや寸いということ ができる。

以上の考え方に基づく確摔最大化配分理論の定式化に ついては，すでに発表した著者の論文 ${ }^{2)}$ の中で詳しく論 じられているので, 本文ではその結果だけを示すと, こ の配分理論による解は, 次式を最小化することによって 与えられることになる。

$$
r \sum_{i} \sum_{k} y_{i}{ }^{k} t_{i}{ }^{k}-\left(-\sum_{i} \sum_{k} y_{i}{ }^{k} \log y_{i}{ }^{k}\right)
$$

ここに $y_{i}{ }^{k}$ は $i(i=1,2, \cdots, r)$ なる OD 交通鱼 $X_{i}$ の うち, 経路 $k(k=1,2, \cdots, s)$ を通る交通量, $t_{i}{ }^{k}$ は $i$ と いら $\mathrm{OD}$ ペア間の経路 $k$ 上の走行時間, また $r$ は経験 的に与えられる定数で $0 \leq r<\infty$ の值をとる。 $y_{i}{ }^{k}$ に ついては次式で与えられる制約条件がある。

$$
\sum_{k} y_{i}{ }^{k}=X_{i}
$$

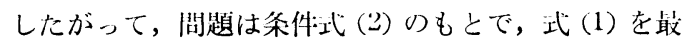
小化すればよいことになり，こ机は数学的にはラグラン ジュの末定乗数法によって解ける。いま, $t_{i}{ }^{k}$ が交通星 に化存せず, 各経路ごとに一定值を取ると仪定すれば, 求める解は,

$$
y_{i}{ }^{k}=\frac{\exp \left(-\gamma t_{i}{ }^{k}\right)}{\sum_{k} \exp \left(-\gamma t_{i}{ }^{k}\right)} X_{i}
$$

で表わされることになる。上式から明らかなようにここ の配分モデルにおいては, OD 間のすべての指定経路に 0 でない $\mathrm{OD}$ 交通量が配分される。この点において確率 最大化配分法は, 経路選択の一義性を前提とした, いわ ゆる決定論的立場に立つ最短経路配分や等時間原則配分 と本質的に異なっている。

ところで, 確摔最大化配分法においては, 定数 要な役制を果たしている。すなわち, 式（1）から明らか なように， $r=0$ の上き日的関数の第 1 項が消え, 第 2 項（これをトリップ配分エントロピーとよぶ）だけを最 大化（前の符号が筫のため）することになり，このとき OD 交通量は各経路に均等に配分され, 総走行時間は最 大值をとる。一方， $r \rightarrow \infty$ のときは, 第 1 項が第 2 項 に比べて支配的となり, 結局総走行時間を最小化する輸 送計画的配分と一致する。すなわち, 定数 $r$ は対象とす る交通量の総走行時間のサイズを決定する役制を果たし
ており, 特に $r \rightarrow \infty$ のときは, 総走行時間が最小値を とり,このときの配分パターンとしては総走行時間最小 化配分しか起こりえないということである。なお，実際 の配分問題に用いる $r$ 值は, 対象とする道路網におい て配分交通量の実績值が与えられておれば，その実績值 との適合度が最大となるように最小二乗法によって決め るか，あるいは道路網上での総走行時間（または 1 台あ たりの平均走行時間) の実績值が与えられる場合は，配 分咕算による走行時間が実績の走行時間の値に一致する ようなとを選心゙ばよいであろう。

\section{3. 走行時間関数を導入したとき}

より実際に近い交通量配分を行おうとすれば，たとえ ば交通混雑による走行時間の増大（または走行速度の低 下）の影響，あるいは道路容量に関する制約条件の導入 が必要となる。ところで, 交通量配分問題に容量制約の 亚念を導入する具体的方法として, 本文では交通混雑に よる走行時間の増大の影響を，交通量一走行時間曲線 (以下，走行時間関数とよぶ）の導入によって考虑する 方法と, 值接各道路区間の容量制限を不等式条件の形で 与える方法の 2 つを考えてみることにした。前者の方法 は, 現実の交通現象にみられる交通量の增加による走行 時閒の増大の影響を，直接配分手法の中に組み入れたも のであるから，現奏の交通現象に近い配分を叮能ならし めるといえ，したがって，リアルタイム的な交通現象を 対象とした交通量配分に適した方法であるといえる。

さて, いま道路網の各道路区間 (以下リンクとよぶ) ごレに走行時間関数を設定する。すなわち，対象とする 道路網が $l$ 本のリンクから構成されているとして, その らちリンク $h(h=1,2, \cdots, l)$ 上の走行時間を, そのリ ンク上の交通量の関数として, 一般に次のように表わし ておく。

$$
T_{h}\left(\sum_{i} \sum_{k} h^{\delta_{i}}{ }^{k} y_{i}{ }^{k}\right)
$$

ここに $h^{\delta^{0}}{ }^{k}$ は $i$ なる OD をもつ経路 $k$ が, リンク $h$ を含むとき 1 , 含まないとき 0 の值をとる定数である。 このとき当該道路網全体での総走行時閒は, 各リンクの [交通荲入走行時間]の和として

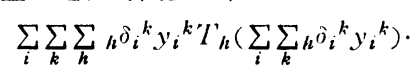

のように表わせる。

よって, 走行時間関数を導入したよきの確率最大化配 分法は,

$$
\begin{aligned}
& r \sum_{i} \sum_{k} \sum_{h} h_{h_{i}}{ }^{k} y_{i}{ }^{k} T_{h}\left(\sum_{i} \sum_{k} h_{h_{i}}{ }^{k} y_{i}{ }^{k}\right) \\
& +\sum_{i} \sum_{k} y_{i}{ }^{k} \log y_{i}{ }^{k}
\end{aligned}
$$

を先に示した OD交通量に関する制約条件式 (2)のもと 
で最小化する問題として定式化される。この場合も先の 場合と同様にラグランジュの未定乗数法によって解か れ, 結局解として,

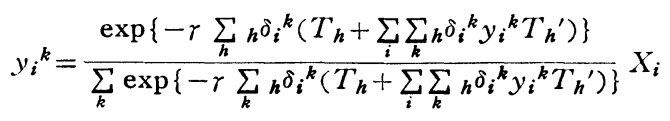

を得る。ただし, 上式において, $T_{h}{ }^{\prime}$ は走行時間関数 $T_{h}$ のリンク交通量に関する 1 階導関数である。しかしなが ら, 走行時間関数を導入した確率最大化配分法において は, 求める解 $y_{i}{ }^{k}$ を陽表的に求めることが困難となる。 そこでリンク交通量を

$$
\sum_{i} \sum_{k} h^{\delta_{i}}{ }^{k} y_{i}{ }^{k}=Q_{h}
$$

とおいたとき

$$
F_{h}\left(Q_{h}\right)=T_{h}+Q_{h} T_{h}{ }^{\prime}=-\frac{d}{d Q_{h}}\left\{Q_{h} T_{h}\right\}
$$

で表わされる仮想的な走行時間関数 $F_{h}(h=1,2, \cdots, l)$ を遒人すれば, 先の式 (7) は

$$
y_{i}{ }^{k}=\frac{\exp \left(-r \sum_{h} h^{\left.\delta_{i}{ }^{k} F_{h}\right)}\right.}{\sum_{k} \exp \left(-r \sum_{h} h^{\left.\delta_{i}{ }^{k} F_{h}\right)}\right.} X_{i} .
$$

となるので，上式を用い，次のような反復計算によ。 て, 走行時間を逐次修正しながら $y_{i}{ }^{k}$ を求める方法を提 案する。

手順 1) rを仮定し,さらに式 (9) で与えられる仗想 的な走行時間関数 $F_{h}$ において, リンク交通量が 0 のと きの值(これを $F_{h}{ }^{(1)}$ とおく) を用いて, 式 (10)より 配分交通量 $y_{i}{ }^{k}$ を婛算する。

手順 2) 各リンクごとに,所定のかりの走行時間関数 によって新たなかりのリンク走行時間 $F_{h}{ }^{*(1)}$ を求める。

手順 3） 2 回目の反復計算に用いるかりのリンク走 行時間 $F_{h}{ }^{(2)}$ を次の修正式

$$
F_{h^{(2)}}=\frac{m F_{h}^{(1)}+F_{h}{ }^{*(1)}}{m+1}
$$

によって求める。ただし，上式の $m$ はこの収束計算を 安定させるために導入される定数で, 問題により適当に 選ばれる。なお， $m$ の与え方については，後述の計算例 の中であらためて検討する。

手順 4) 手順 1)に突り, $F_{h}^{(1)}$ の代わりに $F_{h}^{(2)}$ t 用いて胡算が繰返される。一般に $n$ 回目 $(n=2,3, \cdots)$ の 反復胡算に用いるかりのリンク走行時間 $F_{h}{ }^{(n)}$ は,

$$
F_{h}^{(n)}=\frac{m F_{h}^{(n-1)}+F_{h}{ }^{*(n-1)}}{m+1}
$$

によって与えられ, この反復計算は $F_{h}{ }^{(n)}$ と $F_{h}{ }^{(n+1)}$ が 一致するまで続けられる。

手順 5) 最終的に得られたかりのリンク走行時間を 用いて, 配分交通量が求められる。また, そのときの真 のリンク走行時間 $T_{h}$ は, 式 (9) の関係から逆算すれば

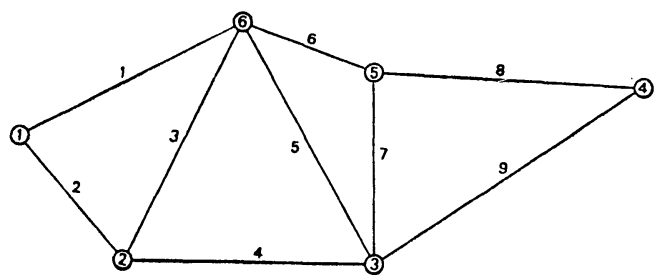

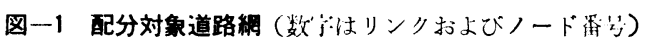
よい。

以上のように走行時間関数を導人した確摔茸大化配分 法は, リンクの走行時間を逐次修正することによって， 解が求められるが，このとき解の存在とその唯一性が保 証されていなければならない。ところで，いま $0 \leq y_{i}{ }^{k}$ $\leq X_{i}(i=1,2, \cdots, r, k=1,2, \cdots, s)$ の範囲において, 走行時間関数 $T_{h}$ が微分可能で, かつその 1 階導関数, 2 階導関数がいずれも非負のとき，すなわち，走行時間 関数 $T_{h}$ が単調増加でかつ広義の凸関数ならば, 先の目 的関数 (6)の 2 階尊関数は非賁となり,よって, 目的関 数が広義の凸関数となることが証明できる。よって，上 述の条件を満足する走行時間関数を用いる限りにおい て, 解がただ一つ存在することが保証される。

\section{計 算 例}

胡算例として図一1に示すような道路網を対象とした 配分問題を解いてみよう。道路網上の $\mathrm{OD}$ 交通量は表一 1 のように与えられており，また，各 $\mathrm{OD} こ ゙ と に 2$ 本の 経路を指定しておく。すなわち， $s=2$ である。これら の経路をパス行列によって表わすと, 次のとおりであ る。

第 1 経路

経 $\begin{aligned} & k_{1}{ }^{1} \\ & k_{2}{ }^{1} \\ & k_{3}{ }^{1} \\ & k_{4}{ }^{1} \\ & k^{1}{ }^{1}{ }^{1} \\ & k^{1}{ }^{1} \\ & k_{6}{ }^{1} \\ & k_{7}{ }^{1} \\ & k_{8}{ }^{1} \\ & k_{9}{ }^{1} \\ & k_{10}{ }^{1}\end{aligned}\left[\begin{array}{lllllllll}1 & 2 & 3 & 4 & 5 & 6 & 7 & 8 & 9 \\ 0 & 1 & 0 & 1 & 0 & 0 & 0 & 0 & 0 \\ 1 & 0 & 0 & 0 & 0 & 1 & 0 & 1 & 0 \\ 1 & 0 & 0 & 0 & 0 & 1 & 0 & 0 & 0 \\ 1 & 0 & 0 & 0 & 0 & 0 & 0 & 0 & 0 \\ 0 & 0 & 0 & 1 & 0 & 0 & 0 & 0 & 0 \\ 0 & 0 & 1 & 0 & 0 & 1 & 0 & 0 & 0 \\ 0 & 0 & 1 & 0 & 0 & 0 & 0 & 0 & 0 \\ 0 & 0 & 0 & 0 & 0 & 0 & 0 & 0 & 1 \\ 0 & 0 & 0 & 0 & 1 & 0 & 0 & 0 & 0 \\ 0 & 0 & 0 & 0 & 0 & 1 & 0 & 1 & 0\end{array}\right]$

表一1 配分対象 OD 交通量

\begin{tabular}{c|c|c|c|c|c|c}
\hline (1) & (2) & (3) & \multicolumn{1}{c|}{$(4)$} & \multicolumn{1}{c|}{ (5) } & (6) & \\
\hline$*$ & $*$ & 1700 & 400 & 700 & 1100 & (1) \\
& $*$ & $*$ & 800 & 1500 & 1300 & (2) \\
& & $*$ & 1200 & $*$ & 1400 & (3) \\
& & & $*$ & $*$ & $* 900$ & (4) \\
& & & & $*$ & $*$ & (5) \\
& & & & & $*$ & (6) \\
\hline
\end{tabular}




\section{表一2 非線形走行時間関数の係数}

\begin{tabular}{c|l|l|l}
\hline リンク番号 & $a_{h}$ & $b_{h}$ & $c_{h}$ \\
\hline 1 & $0.43 \times 10^{-9}$ & $1.03 \times 10^{-3}$ & 6.0 \\
2 & 0.22 & 0.51 & 3.0 \\
3 & 0.36 & 0.86 & 5.0 \\
4 & 0.32 & 0.77 & 4.5 \\
5 & 0.29 & 0.68 & 4.0 \\
6 & 0.13 & 0.31 & 1.8 \\
7 & 0.19 & 0.46 & 2.7 \\
8 & 0.36 & 0.86 & 5.0 \\
9 & 0.43 & 1.03 & 6.0 \\
\hline
\end{tabular}

表一3 非線形走行時間関数を用いた確率最大化配分 $\gamma=0.5$ 配分交通量計算值

\begin{tabular}{|c|c|c|c|c|}
\hline \multirow{2}{*}{ OD } & \multicolumn{2}{|c|}{ 第 1 経 路 } & \multicolumn{2}{|c|}{ 第 2 経 路 } \\
\hline & 配分交通量 & 経路走行時問 & 配分交通量 & 経路起行時間 \\
\hline (1) - - (3) & 1244台/㭙 & 18.32分 & 456台/时 & 21.06 分 \\
\hline (1) - (4) & 286 & 27.08 & 114 & 28.09 \\
\hline (1) $\cdots$ - (5) & 617 & 19.15 & 83 & 21.88 \\
\hline (1) - (6) & 970 & 13.85 & 130 & 16.59 \\
\hline (2) - (4) & 599 & 23.44 & 201 & 25.16 \\
\hline (2) - (5) & 672 & 17.23 & 828 & 17.35 \\
\hline (2) $-(6)$ & 1300 & 11.94 & 0 & 20.87 \\
\hline (3) - (4) & 849 & 9.77 & 351 & 11.61 \\
\hline (3) $\cdots$ (6) & 1309 & 7.20 & 91 & 8.98 \\
\hline (4) - (6) & 785 & 13.22 & 115 & 16.97 \\
\hline
\end{tabular}

第 2 経路

$k_{1}{ }^{2}$
$k_{2}{ }^{2}$
$k_{3}{ }^{2}$
$k_{4}{ }^{2}$
$k^{2}$
$k_{i_{3}}{ }^{2}{ }^{2}$
$k_{6}{ }^{2}$
$k_{7}{ }^{2}$
$k_{8}{ }^{2}$
$k_{9}{ }^{2}$
$k_{10}{ }^{2}$$\left[\begin{array}{lllllllll}1 & 2 & 3 & 4 & 5 & 6 & 7 & 8 & 9 \\ 0 & 1 & 0 & 1 & 0 & 0 & 0 & 0 & 1 \\ 0 & 1 & 1 & 0 & 0 & 1 & 0 & 0 & 0 \\ 0 & 1 & 1 & 0 & 0 & 0 & 0 & 0 & 0 \\ 0 & 0 & 1 & 0 & 0 & 1 & 0 & 1 & 0 \\ 0 & 0 & 0 & 1 & 0 & 0 & 1 & 0 & 0 \\ 0 & 0 & 0 & 1 & 1 & 0 & 0 & 0 & 0 \\ 0 & 0 & 0 & 0 & 0 & 1 & 1 & 0 & 0 \\ 0 & 0 & 0 & 0 & 1 & 0 & 0 & 0 & 1\end{array}\right]$

ここに，パス行列とは， $i(i=1,2, \cdots, 10)$ なる $\mathrm{OD}$ を もつ経路 $k(k=1,2)$ がリンク $h(h=1,2, \cdots, 9)$ を含む とき 1 ，含まないとき 0 の值をとる要素 $h^{\delta_{i}{ }^{k}}$ からなる 行列である。

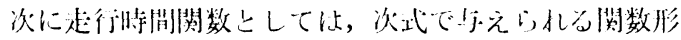
但宩穴てみる。

$$
\left.T_{h}=a_{h}()_{2}\right)^{3}+b_{h}\left(C_{2}+c_{h}\right.
$$

ここに,

$T_{h}$ : リンク $h(h=1,2, \cdots, 9)$ U)尘行時間（分）

$Q_{h}:$ リンク $h$ の交通量（台/時）

$a_{h}, b_{h}, c_{h}$ : リンクの道路条件（延長，幅員など）によ って決まる定数

式 (15) で与えられる曲線は, リンク交通量の増加と ともに，走行時間が急激に增加するように設定された非

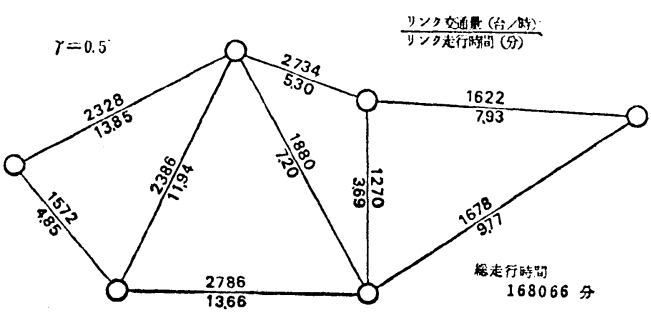

图一2 非線形走行時間関数を用いた確率最大化配分 ーリンク交通量計算值

線形な曲線でありここの湖算例では各リンクごしに係数 $a_{h}, b_{h}, c_{h}$ を表一2 0ように仪定しておく。一少，rは あらかじ経験的におえら机るものであるが，こり、忆算 例に打いては $r=0.5$ 上仮定する。以上の前提のもとで 確摔最大化配分法によって計算したリンク交通量および 配分交通量をそれぞれ図一2および表一3に示す。

さて, 走行時間関数を導入したときの解法において問 題となるのは, 逐次近似計算の中で用いられる定数 $m$ の 广え方である。すなわち, リンク交通量の增加とともに 走行時間が比較的綏やかに増大するような走行時間関数 を用いた場合は， $m=1$ で十分収束し解が得られるが， リンク交通量の増加とともに走行時間が急激に増大する ような非線形な走行時間関数を用いたとき，この反復計 算が振動して収束しないことがある。しかし，このよう なときは $m$ の值をある程度大きくとって, 走行時間の 修正を徐々に行らようにすれば，渻は算定し解が得ら れる。ただし，反復回数は増加する。ただ，ｍの与え方 は，問題とする $\mathrm{OD}$ 交通量や道路網パターン，および の值や伋定した走行時間関数などに影響されるので，い まの上ころ問題ごとに試行錯誤的に決定せざるをえな い。ただ，この計算例において， $m$ の值と反復回数およ び計算時間の関倸をみたところ，表一4 に示すような絬 果が得られた。この結果によれば，反復回数の多い場合 は 1 回当りの計算時間が比較的短く, 一方, 反復回数が 少ない場合は逆に 1 回当りの計算時間が長くなる傾向が みられる。したがって，全体の計算時間としてみればそ れほど大きな差がないようである。よって，問題は $m$ い值をある值以下に小さくしたとき，反復訃算が収束せ 势报動起練返寸恐れいある点である。したがって，これ

表-4 $m$ と反復回数, 計算時間との関係

\begin{tabular}{|c|c|c|c|}
\hline$m$ & 反復回数（니） & CPU 部算時間（秒） & $\begin{array}{l}1 \text { 回当门口)計算 } \\
\text { 时間 (秒/回) }\end{array}$ \\
\hline 13 & 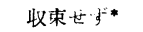 & - & - \\
\hline 15 & 97 & 9.00 & 0.093 \\
\hline 17 & 109 & 8.99 & 0.082 \\
\hline 19 & 122 & 9.57 & 0.078 \\
\hline 21 & 134 & 9.60 & 0.072 \\
\hline
\end{tabular}

* 正確には反復回数か300回越えむものをいう。 
表一5 線形走行時間閶数 の係数

\begin{tabular}{c|l|l}
\hline リンク番号 & \multicolumn{1}{|c|}{$a_{h}$} & $b_{h}$ \\
\hline 1 & 0.0030 & 6.0 \\
2 & 0.0015 & 3.0 \\
3 & 0.0025 & 5.0 \\
4 & 0.00225 & 4.5 \\
5 & 0.0020 & 4.0 \\
6 & 0.0009 & 1.8 \\
7 & 0.00135 & 2.7 \\
8 & 0.0025 & 5.0 \\
9 & 0.0030 & 6.0 \\
\hline
\end{tabular}

を防ぐには，ある程度 $m$ の 值を大きくとって計算する ほかない。ただし，計算プ ログラムをくふうすることによって, 反復計算の途中で $m$ の值を変えることにより, 収束計算を加速し計算時間 を短縮することは可能である。

次に, 式 (15) で与えられる非線形走行時間関数の代 わりに,

$$
T_{h}=a_{h} Q_{h}+b_{h}
$$

で表わされる線形走行時間関数 (ただし, $a_{h}, b_{h}$ の值は 表一5 に示すとおりである）を用いたときの配分交通量 計算結果を 表一6 に示す。表一6 の結果で注目されるこ とは, $r=10$ のときの配分結果がほぼ総走行時間最小化 配分パターンに近くなっていることである。すなわち， ほとんどの OD ペアで交通量が最短経路にのみ配分さ れ，(2)—(4)，(2)—(5)よび(3)—(4)の3つの $\mathrm{OD}$ ペアだけ 2 本の経路に交通量が配分されている。しかも，この 3 つの OD 間では，第 1 経路と第 2 経路の走行時間が, $r=0.5$ の場合に比べて非常に接近してきており，近似 的に等時間原則配分パターンを示しているといえる。こ のように総走行時間最小化配分と等時間原則配分とは, 総交通量がある程度多くなってくるとほぼ一致してくる ことは，すでに理論的に証明されている3)。

\section{4. 容量制限不等式を導入したとき}

次に，容量制約を考慮するための方法として，直接道 路網の各区間における容量制限を不等式条件として導入 する場合について考えてみよう。この方法によれば，あ らかじめ与えられた道路容量以上に交通量が配分される ことはないが, この方法では容量一杯になるまでは, 容 量制約が交通の流れに全く影響をもたないことになり， 交通量の増加とともに徐々にかつ連続的に容量制約の影 響がみられる現実の交通現象を考えれば，いくらか非現 実的であるといえる。

容量制限不等式を用いた確率最大化配分法は次のよう に定式化される。
表一6 線形走行時間間数を用いた確率最大化配分 配分交通昷計算値

$r=10.0$

\begin{tabular}{|c|c|c|c|c|c|c|c|c|c|c|c|}
\hline 第 & 2 & 経 & 路 & 第 & 1 & 経 & 路 & 第 & 2 & 経 & 路 \\
\hline
\end{tabular}

6.62分 246台/時!

19.64分 1700 台/時

17.02 分

25.71

\begin{tabular}{l|l}
27.77 & 400 \\
20.81 & 700
\end{tabular}

$16.31 \quad 1100$

12.60

\begin{tabular}{l|l|l|l}
76 & 16.31 & 1100 & 12.60 \\
\hline
\end{tabular}

759

5

251

42

\begin{tabular}{l|l}
15.48 & 824
\end{tabular}

\begin{tabular}{l|r}
18.06 & 1300
\end{tabular}

$13.33 \quad 1101$

\begin{tabular}{l|l}
8.86 & 1400
\end{tabular}

18.09

900

22.93

14.92
10.51

11.47

6.80

13.11

19.40 分

28.48

20.47

16.06

23.62

15.21

18.27

12.44

8.16

18.27

制約条件

$$
\sum_{i} \sum_{k} h^{\delta_{i}}{ }^{k} y_{i}{ }^{k} \leqq c_{h} .
$$

および

$$
\sum_{k} y_{i}{ }^{k}=X_{i}
$$

のもとで

$$
r \sum_{i} \sum_{k} y_{i}{ }^{k} t_{i}{ }^{k}+\sum_{i} \sum_{k} y_{i}{ }^{k} \log y_{i}{ }^{k}
$$

を最小化せよ。

ここに, $h^{\delta}{ }^{k}, y_{i}{ }^{k}, X_{i}, t_{i}{ }^{k}$ は前に定義したとおりで あり,また, $c_{h}$ はリンク $h(h=1,2, \cdots, l)$ の交通容量 である。すなわち, 式 (17) は各リンクにおける容量制 限を示す不等式条件を与える。

上記のように容量制限不等式を用いた確率最大化配分 法は，等式および不等式条件つきの最小化問題として定 式化され, しかも目的関数 (19) が非線形となるため, いわゆる非線形計画法の問題となることがわかる。現在: 非線形計画法に関寸る解法がいろいろ開発されている が，ここでは制約条件つきの最適化問題を制約条件なし の最適化問題に変換して解く, いわゆるペナルティ関数 法の一種の SUMT 法を適用し, この非線形な配分問題 の実用的求解法を検㶦してみる。特に確率最大化配分法 はその目的関数自身が凸関数であることが証明でき，し たがって解の存在とその唯一性が保証されるので, 非線 形計画法を適用するにはまことに好都合な条件を備えて いるといえる。

SUMT を交通量配分の問題に適用した例はすでにい くつか存在するが4),5),6), SUMT (Sequential Uncon-

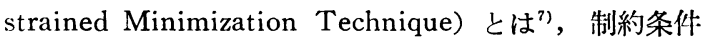
付最小化問題を制約条件なしの最小化問題として解く方 法で，これを上に定式化した容量制限不等式付きの確率 最大化配分法に適用すれば，目的関数式（19）は次のよ らな関数形に変換される。

$$
\begin{aligned}
f\left(\boldsymbol{y}, r_{M}\right) \equiv & r \sum_{i} \sum_{k} y_{i}{ }^{k} t_{i}{ }^{k}+\sum_{i} \sum_{k} y_{i}{ }^{k} \log y_{i}{ }^{k} \\
& +\left(r_{M}\right)^{-1 / 2} \sum_{i}\left(\sum_{k} y_{i}{ }^{k}-X_{i}\right)^{2}
\end{aligned}
$$




$$
+r_{M} \sum_{h} 1 /\left(c_{h}-\sum_{i} \sum_{k}{ }_{h} \sigma_{i}{ }^{k} y_{i}{ }^{k}\right)
$$

この変換をSUMT 変換とよび, 元の制約条件付きの最 小化問題の解を, 制約条件のない最小化問題, 寸なわ ち, 式 (20) の解の $r_{M} \rightarrow 0$ の極限值として求めるのが SUMT の基本的な考え方である。ここに $r_{0}>r_{1}>r_{2}$ $>\cdots r_{M}>r_{M+1} \cdots>0$ である。

SUMT 変換の意味するところは次のとおりである。 すなわち, OD 交通量に関する等式条件が満足されず $\sum_{k} y_{i}{ }^{k}-X_{i} \neq 0$ の場合は, $r_{M} \rightarrow 0$ に対して $f\left(\boldsymbol{y}, r_{M}\right)$ が無限大となり，目的に反することになるので，このよ らなことは実際には起こらず, 安定した最小化の手続き が実行できるときは， $r_{M} \rightarrow 0$ に対して等式条件がしだ いに満足される。一方, 容量制限に関する不等式条件に ついてみれば, 解が制約集合の境界に近ゔくと, やはり $f\left(\boldsymbol{y}, r_{M}\right)$ が無限大となり, 目的に反することになる。 しかし，この場合においても，境界を侵すことなしに $f\left(\boldsymbol{y}, r_{M}\right)$ の最小化が実行される。その結果 $r_{M}$ の值が 0 に近づくにしたがって， $f\left(\boldsymbol{y}, r_{M}\right)$ の解が式 (19) の 最小值に収束することが期待できるのである。したがっ て，上記の性質を満足する関数形であれば一般には何で もよいのであって, SUMT 変換は式（20）に限定して 考える必要はない。

さて，問題は解の収束性であるが，SUMT の収束定 理によれば, 目的関数, 等式条件式, 不等式条件式のい ずれもが連続的に 2 回微分可能であり，かつ凸関数であ ることなどの条件のもとで, $r_{M} \rightarrow 0$ のとき $f\left(\boldsymbol{y}, r_{M}\right)$ の解が真の目的関数式 (19) の最小值の解に近らくこと が証明されるので, よって解が唯一つ存在し, かつ収束 計算によっていくらでもその解に接近できることが保証 されることになる。

なお, SUMT 変換された新しい目的関数式 (20) に おいて, 不等式条件については, 反復計算の各段階で得 られたリンク交通量が，容量制限不等式を越えそらなリ ンクについてだけ考慮すればよく，その危険性の全くな いリンクについては, その容量制限不等式条件を省くこ とが可能で，その分だけ計算量を軽減できる。また，式 (20) において，等式条件にかかる摂動パラメーター $r_{M}$ と不等式条件にかかる摂動パラメーター $r_{M}$ は同一とし たが，これは必ずしもその必要はなく, 問題のスケール によって，異なる摂動パラメーターを用いても差しつか えない。実際異なる搨動パラメーターを用いたほうが計 算量が少なくなることさえある。

SUMT の計算は, 具体的には次の手順によって行わ れる。

手順 1) 容量制限に関する不等式条件式 (17) を満足 する初期值 $\boldsymbol{y}^{(0)}$ を選ぶ。このとき等式条件式 (18)につ
いては考慮する必要がないので, 初期値の選定は容易に 行えるであろう。

手順 2) 最初の捸動パラメーター $r_{0}$ を選び, $f\left(\boldsymbol{y}, r_{0}\right)$ を最小にする $\boldsymbol{y}\left(r_{0}\right)$ を求める。 $f\left(\boldsymbol{y}, r_{0}\right)$ の最小化手法 としては, 後述の Fletcher-Powell 法を採用することに する。さて, $r_{0}$ の選び方であるが, 一般には目的関数の 值に比べて条件式の項が過大となったり, あるいは逆に 過小とならないよう適当に見当をつけて初期值を選べば よいが， $r_{0}$ があまり大きすぎると，制約条件の項が不 当に大きくなって, 解が问能域の中に入ってしまい, 訣 算回数が増え, 一方あまり小さすぎると, 解が可能境界 付近にあって, 求解が困難となることがある。いずれに しても， $r_{0}$ の適当な選択法は問題のスケーリングに関 係している。

手順 3) $0<r_{1}<r_{0}$ なる $r_{1}$ を定め, $\boldsymbol{y}\left(r_{0}\right)$ から始 めて $f\left(\boldsymbol{y}, r_{1}\right)$ を最小にする $\boldsymbol{y}\left(r_{1}\right)$ を求める。

手順 4) 以上の計算を絽返す。なお, $r_{M}(M=0,1$, $2, \cdots)$ の減少には, 一般に定率隇少, 寸なわち $r_{M+1}=$ $r_{M} / c(c>1)$ が用いられる。

さて, $f\left(\boldsymbol{y}, r_{M}\right)$ の最小化の方法であるが，これは制 約条件なしの最小化問題となるから，一般には傾斜法が 適用できる。たとえば, 1 階導関数を用いた最大傾斜法, 2 階導関数を用いた Newton-Raphson 法などがあるが 本文では共役方向を用いた傾斜法の1つである Fletcher Powell 法"8) を用いることにする。Fletcher-Powell 法 は常に収束することが証明されておりこれを先の SUMT 法と組み合わせて用いれば，いま問題としてい る容量制限不等式のある確率最大化法の解法として強力 な武器となるであろう。

\section{計 算 例}

計算例として, 先に示した走行時間関数を導入したと きの計算例を，ここで再び取り上げることにする。計算 の前提となる $\mathrm{OD}$ 交通量, 指定経路は前と全く同様であ る。ただし, 今回の場合は走行時間を一定とし, その傎 は式（15）でリンク交通量を0 と置いたときの走行時閒 を採用する。その代わり各リンクに容量制限が課せら れ，リンク容量をすべて 3000 台/時 と仮定する。次に 配分交通量 $\boldsymbol{y}$ の初期值であるが，これは不等式条件を 満足する点を選ぶ必要がある。このとき，等式条件につ いては考慮する必要がないので, 初期値としてある程度 小さめの值を取っておけば，おのずと不等式条件を満足 することになる。ここではすべての $y_{i}{ }^{k}$ の初期値として 100 を仮定する。次に昹動パラメーターの初期值 $r_{0}$ の 值としては, 問題のスケールから判断し $r_{0}=10^{4}$ を仮定 し, また $r_{M}$ の減少ステップとして， $r_{M+1}=r_{M} / 10$ な る定率減少を採用した。

以上の準備のもとで， $r=0.5$ と与えられた場合の配 
分計算を行ってみた。その結果配分交通量につい ては表一7に,またリンク交通量については表一 8 に示すような解を得た。この計算においては, 収束判定のための基準を相対誤差 $0.5 \%$ 以下と仮 定したが, この計算例では $r_{5}=0.1$ の段階で解が 収束しており,そのシーケンスの回数は 6 回であ る。また,この収束解では, 2 本の経路への配分 交通量の和が OD 交通量に一致しており, 最終的 には等式条件が満足されていることがわかる。ま た，表一8に得られたリンク交通量は，いずれも 3000 台/時の容量制限以下に抑えられていること もわかる。

ところで, この配分計算では, 最初不等式条件 をすべてのリンクで省略して計算を始めたが, 反 復計算の途中でリンク 4 と 6 においてリンク交通 量が容量を越えたので, 結果的にはこの 2 つのリ ンクについてのみ容量制限不等式が導入されてい る。

容量制限不等式を用いた確率最大化配分法の解法とし て, SUMT 法を援用したときの問題点として, 捸動パ ラメーター $r_{M}$ およびその減少 ステップ幅をいかに合 理的に与えるかという点があげられる。表一9 は攝動パ ラメーターの初期值 $r_{0}$ を变化させて計算したときの（他 の条件は全く同じとして）解が収束するまでの $r_{M}$ の減 少シーケンス回数 $(N)$, SUMT 変換された目的関数を よぶ延回数 $(M)$ ，および計算時間 (CPU time) を比較 したものである。この表の結果によれば, $r_{0}$ と計算回数 および計算時間との間には, それほど目立った傾向がみ られない。ただ先に述べたように，r $r_{0}$ をまり小さくと ると，等式条件が強くきいて最小化を実行することが困 難となることがある。一方， $r_{0}$ を大きくとり過ぎると， 逆に不等式条件の項が不当に重くなって, 解が可能域の 中に入ってしまうため, 計算回数が非常に増えてしまう ことになる。いずれにしても，roの值は問題のスケーリ ングに関係しており，本来の目的関数の值に比べて，条 件式の項が過大または過小にならないよう問題ごとに決 定すべきであると判断される。また， $r_{0}$ の決定には $y_{i}{ }^{k}$ の初期値にも関係してこよう。また，すでに述べたよう に, 等式条件にかかる摂動パラメーターと不等式条件に
表一7 容贯制限不等式を用いた確率晨大化配分一欺分交通量計算值 $\gamma=0.5$ 摂動パラメーターの初期值 $r_{0}=10^{4}$ 減少ステップ $=1 / 10$

(単位：台/時)

$\begin{array}{r}\text { 関数呼出し回数 } \\ \hline r_{k} \text { の減少ステップ }\end{array}$

かかる捸動パラメーターは，必ずしも同じである必要は なく，补算プログラムの中でくふらすることにより，閯 題に応じて捸動パラメーターの值を変えてもよい。

次に, 摂動パラメーター $r_{M}$ を定率減少させた場合の 減少ステップ幅 $c$ についてみると, 表一10 は $c=2,5$, 10,15 としたときの計算回数と計算時間を比較したもの である。この結果によれば, $c$ を大きくとれば $r_{M}$ の減

\section{表一g $r_{k}$ の初期值と計算回数・計算時間の関係}

\begin{tabular}{l|c|c|c|c|c|c}
\hline & \multicolumn{3}{|c|}{$r=0.5$} & \multicolumn{3}{c}{$r=0.1$} \\
\cline { 2 - 6 } & $r_{0}=10^{4}$ & $r_{0}=10^{5}$ & $r_{0}=10^{6}$ & $r_{0}=10^{2}$ & $r_{0}=10^{3}$ & $r_{0}=10^{4}$ \\
\hline$N$ (回) & 6 & 7 & 7 & 7 & 9 & 9 \\
$M$ (回) & 98 & 118 & 100 & 132 & 151 & 170 \\
$C P U$ Time (sec) & 48.74 & 54.33 & 49.24 & 55.30 & 63.80 & 67.35 \\
\hline
\end{tabular}

$N: r_{k}$ のンーケンス回数 $M:$ 関数呼出し回数

表一10 $r_{k}$ の減少ステップ幅と計算回数・計算時間の関係

\begin{tabular}{l|c|c|c|c}
\hline & $c=2$ & $c=5$ & $c=10$ & $c=15$ \\
\hline$N$ (回) & 11 & 6 & 6 & 5 \\
$M$ (回) & 104 & 80 & 88 & 81 \\
$M / N$ & 9.5 & 13.3 & 14.7 & 16.2 \\
CPU Time (sec) & 45.74 & 37.41 & 40.25 & 39.54 \\
\hline
\end{tabular}

$N: r_{k}$ のシーケンス回数 $M:$ 関数呼出し回数

表一8 容量制限不等式を用いた確率最大化配分ーリンク交通目計算值

$\gamma=0.5$ 撕動パラメーターの初期值 $r_{0}=10^{4}$ 減少ステップ $1 / 10$

（単位：角/時）

\begin{tabular}{|c|c|c|c|c|c|c|c|c|c|c|c|}
\hline $r_{k}$ の減少ステッブ & 関数呼出し回数 & リンク 1 & リンク 2 & リンク 3 & リンク 4 & リンク 5 & リンク 6 & リンク 7 & リンク 8 & リンク 9 & 容量チェック \\
\hline$r_{0}=10^{4}$ & 37 回 & 2114 & 1702 & 2361 & 2889 & 2374 & 2190 & 1492 & 1132 & 2088 & \\
\hline$r_{1}=10^{3}$ & 12 & 2076 & 1800 & 2520 & 2862 & 2052 & 2673 & 1540 & 1354 & 1922 & リンク 4 \\
\hline$r_{2}=10^{2}$ & 16 & 1996 & 1896 & 2548 & 2943 & 1853 & 2875 & 1581 & 1428 & 1864 & リンク 4 \\
\hline$r_{3}=10$ & 14 & 1978 & 1920 & 2540 & 2978 & 1799 & 2955 & 1602 & 1469 & 1829 & \\
\hline$r_{4}=1$ & 10 & 1971 & 1929 & 2535 & 2993 & 1792 & 2956 & 1606 & 1467 & 1833 & リンク 6 \\
\hline$r_{5}=10^{-1}$ & 9 & 1971 & 1929 & 2535 & 2993 & 1794 & 2953 & 1606 & 1466 & 1834 & リンク 6 \\
\hline
\end{tabular}


少シーケンス回数 $(N)$ は減少するが, 1 回のシーケン ス当りの関数呼び出し回数 $(M / N)$ が増えるので, 結 局計算時間としてみればそれほど大きな差がみられな い。したがって，この計算例だけでは断定することはも ちろんできないが, 求解のための労力は $c$ の選定とあま り関倸がないように思われる。

容量制限不等式を用いた確率最大化配分法の解法とし ては, 上記の SUMT のほか, 目的関数の線形近似によ って, 線形計画法として解く方法も考えられる。特に確 率最大化配分法の場合目的関数が変数分離型で与えられ ているので, 線形近似するには好都合である。しかも目 的関数が各変数について凸関数であることが証明されて いるので, 最小解が唯一つ存在することが保証される。 しかしながら, 線形近似による方法は, 変数の数が増え るため, 特に大規模な配分問題には適用が困難となる。

\section{5. リンクフローによる確率最大化配分法の定 式化}

前節まで取り扱われてきた確率最大化配分法は, いわ ゆるパスフローとして定式化されている。したがって， 道路網上であらかじめ各 $\mathrm{OD}$ ごとに配分対象経路を何本 か指定し，それぞれの経路に配分される交通量が変量と して取り扱われる。このようにパスフローによる定式化 によれば, OD 間の配分対象経路が限定できるため, 扱 う变数の数を少なくできる利点をもっているが，その仅 面配分补算に先立って各 $\mathrm{OD}$ 間に何本かの経路を指定寸 るための経路探索といら百倒な作業を必要とするし，さ らに, 指定する経路およびその本数によって, 陀分解が 変化するという基本的な問題点を含んでいる。

ところで，パスフローによる確率最大化配分法におい ては, あらかじめ指定された経路に配分される交通最を もとに微視的状態というものが考えられたが，このとき の経路に代わるものとして道路区閒（リンク）を取り, リンク上の本の分布状態をべースにした微視的状態とい うものを考えたとしても，配分理論自体としては本質的 な違いはない。これはいわゆるリンクフローとしての確 率最大化配分法ということであり, この場合は道路網に 配分される各OD交通量がリンクごとに変量として取り 扱われる。

\section{表一11 容量制約の導入方法と計算時間}

\begin{tabular}{|c|c|c|}
\hline 容酉制約の道入方法 & $\begin{array}{l}\mathrm{CPU} \\
\text { 計算時間 }\end{array}$ & 考 \\
\hline 走行時間関数を (線 形関 数 & 6.50 秒 & $m=3$ \\
\hline 導入したとき 非線形関数 & 9.00 & $m=15$ \\
\hline 容量制限不等式を递入したとき & 37.41 & $\begin{array}{l}y_{i}{ }^{k} \text { の初期= all } 400 \\
r_{0}=10000, \\
\text { 减少ステップ=1/5 }\end{array}$ \\
\hline 容量制的を考慮しないとき & 0.64 & \\
\hline
\end{tabular}

このとき問題は次のように定式化される。すなわち， いま道路網の各ノード（分忮点）に番号をつけ, リンク はその両端のノード番号によって表わすことにして,リ ンク $i, j$ 上の走行時間を $t_{i j}$, リンク $i j$ の容量を $c_{i j}$, $k$ なる OD のリンク $i j$ に配分される交通量を $y_{i j}{ }^{k}, k$ なる $\mathrm{OD} の \mathrm{OD}$ 交通量を $X_{k}$ とする。このとき目的 関数は,

$$
r \sum_{i} \sum_{j} \sum_{k} t_{i j} y_{i j}{ }^{k}+\sum_{i} \sum_{j} \sum_{k} y_{i j}{ }^{k} \log y_{i j}{ }^{k} \ldots \ldots
$$

となりこれを次の連続条件

$$
\sum_{j}\left(y_{i j}{ }^{k}-y_{j i}{ }^{k}\right)=\left\{\begin{aligned}
X_{k}: i \text { が交通発生ノードのとき } \\
-X_{k}: i \text { が交通集中ノードのとき } \\
0: 0
\end{aligned}\right.
$$

容荲制限条件

$$
\sum_{k} y_{i j}{ }^{k} \leqq c_{i j}
$$

および非負条件

$$
y_{i j}{ }^{k} \geqq 0 .
$$

のもとで最小化する問題となる。

特に容量制限不等式の代わりに, リンク走行時間を走 行時間関数で与えてもよい。いずれにしても問題は非線 形泟画法の問題となり, 一般的解法としては, 先に提案 した SUMT 法上Fletcher-Powell 法がやはり有効であ ろう。

\section{6. あとがき}

本文で議論してきた容晴制約のある確率最大化配分法 は，あくまでも現垁の交通量配分現象の正確な記述をめ ざしたものであるが，微視的状態というものに基礎を置 いた最確配分パターンが，果たして現実に実現している のかどらかは全く別の問題であって,これはやはり実際 の配分問題への適用を通して，その適合性を検討してい か㸚ばならず，この点に関しては今後の課題である。

ところで, 本文では容量制約の考え方として, 走行時 開関数を導入する方法々容量制限不等式条件を導入する 方法を提案したが，この雨者を比較すれば，配分パタ一 ンの記述的モデルとしては前者のほらが現実的であり, また計算の労力からみても実用的であるといえる。表一 11は同一の配分問題に対して, 走行時間関数を導入した 場合と容量制限不等式条件を導入した場合の CPU 部算 時間を比較したものである。

なお, 交通量配分問題に共通した問題点として, 走行 時間関数の設定方法, 交通容量の考え方, 配分経路の指 定, 街路網を対象とするときのターンペナルティの与え 方などがあげられ，これらの問題は本文で提案した確率 最大化配分法の実用性と適合性に大きくかかわりをもつ きわめて重要な要素である。しかし，これら交通量配分 
に付随した諸問題については本文では検討されておら

ずしたがって今後の研究課題としたい。

最後に, 本論文の甜算には名古屋大学大型尌算機セン

ターの FACOM 230-60 を使用したことを付記してお $<。$

\section{考文 献}

1）松井 寛: 確率最大化による交通量配分理論, 交通工学 Vol. 6, No. 5, pp. 3 11, 1971 年 9 月.

2) 前掲 1) に同じ

3）井上博司：輸送計画的配分 および 等時間原則による配分 に関する研究，土木学会第 25 回年次学術講演会講演概要 集, 第 4 部, pp. $113 \sim 114,1970$ 年 11 月.
4）森口繁一・伊理正夫・長谷 彰：多種流輸送問題の一つの 逐次近似解法, 1970 年度日本 $O R$ 学会秋季研究発表会厂 ブストラリト集 pp. $21 \sim 22,1970$ 年 11 月.

5）松井 寞：非線形な走行時間関数を用いた輸送尌画的配 分, 第 10 回日本道路会議一般論文集, pp. 15 16, 1971 年 10 月.

6）新手法による高速道路交通流の推計 (第 2 章), 日本 $O R$ 学会報文シリーズ T-73-2, 1973.

7) Fiacco A.V. and McCormick G.P. : Nonlinear Programming-The Sequential Unconstrained Minimization Technique, Wiley, New York, 1968.

8）志水清孝：システム制御と数理計画法, コロナ社, 1971. 